\title{
FACTORS IN CULTURE MEDIA AFFECTING THE GROWTH, AND PIGMENT CONTENTS OF ALGA TRENTEPOHLIA MONILIA
}

\author{
SARAPHOL, S. - VAJRODAYA, S. - WONGKANTRAKORN, N. - SANEVAS, N.* \\ Department of Botany, Faculty of Science, Kasetsart University, 50, Ngam Wong Wan Road, \\ Lat Yao, Chatuchak, Bangkok 10900, Thailand \\ (phone: +66-2562-5555 ext. 646301; fax: +66-2940-5627) \\ *Corresponding author \\ e-mail: fscintsv@ku.ac.th; phone: +66-2562-5555 ext.646329; fax: +66-2940-5627
}

(Received $14^{\text {th }}$ Jan 2021; accepted $9^{\text {th }}$ Apr 2021)

\begin{abstract}
A genus Trentepohlia is the major type of filamentous subaerial green alga that grows in tropical zones. Its species have a yellow to red colour because of a large amount of total carotenoids. Trentepohlia monilia, a dominant Trentepohlia species, was investigated during the winter season at 720 metres above sea level in the Chiang Dao Wildlife Sanctuary, Chiang Mai Province, in northern Thailand. Growth of the species in different liquid culture media was measured to find the best such medium, and various factors in the media were measured to determine which ones resulted in the highest amount of total carotenoids. The results showed that the enriched seawater medium (ESM) liquid culture produced the maximum growth of the species in week 9 of the study and also produced the highest total carotenoid content. A pH of 7.0, with an added peptone of $1 \%$, culture strength of $50 \%$, nitrogen source of -0.50 times and vitamin $\mathrm{B}_{12}$ source of -0.50 times the usual concentration in the ESM generated the optimum conditions for growing T. monilia and also produced a total carotenoid content that was higher than the total chlorophyll content. This level of growth could make the species a future source of carotenoids for industrial products.
\end{abstract}

Keywords: Chiang Dao Wildlife Sanctuary, subaerial green algae, enriched seawater medium, chlorophyll content, total carotenoid content

\section{Introduction}

The genus Trentepohlia Martius, a subaerial or terrestrial alga, is the largest genus in the Trentepohliaceae family, belonging to the Trentepohliales order, Ulvophyceae class and Chlorophyta division (John, 2002; López-Bautista et al., 2002; Rindi, 2007; Rindi et al., 2009; Guiry and Guiry, 2015; Lemes-da-Silva et al., 2017). The alga grows on a wide range of substrata, from soils, rocks, bark, stems, and the leaves of trees to various manmade constructions (John, 2002, 2003; López-Bautista et al., 2002; Rindi, 2007; Rindi et al., 2009, 2018; Guiry and Guiry, 2015; Kharkongor and Ramanujam, 2017; Binoy et al., 2019). It is the most diverse and dominant of the subaerial algae that are abundant in tropical and subtropical regions (John, 2002; López-Bautista et al., 2002; Rindi, 2007; Rindi et al., 2009, 2018; Allali, 2011; Binoy et al., 2019). In addition, all Trentepohlia species produce a large amount of total carotenoids, which protects them from ultraviolet light or high irradiance. The pigment of the carotenoids gives the algae a yellow, orange or red color that is easily recognizable in natural habitats (López-Bautista, 2008; Rindi et al., 2018). Of the carotenoids, $\beta$-carotene is the one most abundantly found in this genus (Czeczuga and Maximov, 1996; Abe et al., 1998, 1999; Mukherjee et al., 2010; Aburai et al., 2013; Chen et al., 2015; Rindi et al., 2018; Binoy et al., 2019). Many scientists have suggested, therefore, that these algae could be used as a rich source of foods or supplementary foods for humans, natural food colorants, animal feeds, cosmetics and medicines (e.g., as a source of vitamin A, an enhancer of the immune response, an antioxidant or an anticancer agent) (Mortensen, 2006; Rao and Rao, 2007; Cazzonelli, 2011; Guedes et al., 2011; Takaichi, 2011; Priyadarshani and Rath, 
2012; Eldahshan and Singab, 2013; Kharkongor and Ramanujam, 2017). Many scientists around the world have been sampling Trentepohlia species to culture and isolate their total carotenoid content (López-Bautista, 2008; Rindi et al., 2009; Aburai et al., 2013; Chen et al., 2015), but no one has done it yet in Thailand. Therefore we collected Trentepohlia monilia De Wildeman, a dominant species, from the Chiang Dao Wildlife Sanctuary, Chiang Mai Province, in northern Thailand, which has the highest limestone mountain in the country and the third highest overall.

Our study aimed to examine the optimum factors that would enhance the growth of T. monilia by collecting samples of the alga from natural sites. Samples were taken to the laboratory, and various liquid culture media were used for growing the algae. We measured the growth of the algae to find which liquid culture medium was the best one. When we found the best medium, we attempted to determine which of its factors were involved in producing the highest total carotenoid content. This study of $T$. monilia could be the first step in gathering data that could stimulate the development of algal carotenoids as a marketable product in Thailand.

\section{Materials and methods}

\section{Sampling area}

The filamentous subaerial green alga $T$. monilia was collected from a curved steel barrier at points along the Ban Yang Thung Pong and Sop Hui Pha Tang Na Lao trails in the Chiang Dao Wildlife Sanctuary, Chiang Mai Province, northern Thailand, at 720 metres above sea level (latitude $19^{\circ} 22.588^{\prime}$ North and longitude $98^{\circ} 45.080^{\prime}$ East). Most of the samples were found in a dry evergreen forest. The algae were collected during the winter (dry season).

\section{Algae materials}

The algal samples were collected by following Saraphol et al. (2020), with a sterile scraper and placed into plastic boxes for further identification and culturing. Some environmental factors, such as the type of substrate on which the algae were found and their colour and preliminary morphologic characteristics, were observed and noted to help with identifying the samples correctly.

\section{Algae identification}

The algal samples were freeze-dried at $-4{ }^{\circ} \mathrm{C}$ in the laboratory. Identification of T. monilia was done under the Olympus SZ30 stereomicroscope, Olympus CH30 light compound microscope (both from the Olympus Corp., Tokyo, Japan) and scanning electron microscope (Quanta 450 FEI, Thermo Fisher Scientific, Inc., Hillsboro, Oregon, United States) using the floristic keys and algae base website of López-Bautista et al. (2002), John (2002, 2003) and Guiry and Guiry (2015).

\section{Algae sampling and culture}

Once the algal samples had been collected from their habitats, they were kept in plastic boxes until used for further study. They were then cleaned by submersion in $70 \%$ ethanol and $1.2 \%$ sodium hypochlorite for 5 minutes. Each sample was transferred to a $1.5 \mathrm{ml}$ Eppendorf tube, which contained one of seven liquid media: enriched seawater medium (ESM), BG-11 medium, Jaworski's medium (JM), Bold's basal (BB) medium with 
$\mathrm{NaNO}_{3}$ or $\mathrm{NH}_{4} \mathrm{Cl}$ source, Bristol medium (BM), high-salt medium (HSM), and tris-acetate-phosphate (TAP) medium in the field. Upon arrival at the Department of Botany, Kasetsart University, each sample was transferred from its Eppendorf tube to a sterile $250 \mathrm{ml}$ Erlenmeyer flask containing one of the seven media.

The subaerial green algal cells of $T$. monilia were grown on a shelf at room temperature $\left(25^{\circ} \mathrm{C}\right)$ under continuous illumination by cool-white fluorescent lamps $(3,000$ lux $)$ with a light-to-dark ratio of 12:12 for 3 months. During this time, the algae were subcultured for purification to an axenic culture. The cells grew and increased by large amounts. The subaerial green algal cells were identified by microscope again as being T. monilia.

\section{Measurement of algae growth}

T. monilia cells grown for six months were shaken, and then $10 \mathrm{~mL}$ of a minimum of about $0.1 \mathrm{~g}$ algal fresh weight were transferred to a sterile $100 \mathrm{ml}$ Erlenmeyer flask, which contained a liquid medium on the shaker. The optical density of algal growth was set as 0.1 at $550 \mathrm{~nm}$. The growing cells were shaken at $100 \mathrm{rpm}$, at $25^{\circ} \mathrm{C}$, under continuous illumination by cool-white fluorescent lamps (3,000 lux) with a light-to-dark ratio of 12:12. The growth of cells in each $10 \mathrm{ml}$ was measured every week from week 1 to week 11. The photosynthetic pigments in the total chlorophyll (a and b) and the total carotenoid content were measured with the spectrophotometer methods of Pompelli et al. (2013) and Chen et al. $(2015,2016)$. The pigment contents were calculated as follows:

$$
\begin{gathered}
\text { Chlorophyll a content }(g / l)=(12.19 A 665)-(3.45 A 649) \\
\text { Chlorophyll b content }(g / l)=(21.99 A 649)-(5.32 A 665) \\
\text { Total carotenoid content }(g / l)=\frac{[(1000 A 480)-(2.14 \text { Chlorophyll a }-(70.16 \text { Chlorophyll b) }]}{220} \\
\text { Car } / \text { Chl ratio }=\frac{\text { Total carotenoid content }}{\text { Chlorophyll a content }+ \text { Chlorophyll b content }}
\end{gathered}
$$

The algae in different media were analyzed to find the best medium for optimal growth so this medium could be used in the next experiment.

\section{Analysis of various liquid culture factors}

The best strain of algae in the best liquid culture medium was chosen based on previous studies to evaluate the various liquid culture factors (Table 1) that might have affected it.

The first $T$. monilia cells were evaluated every week from week 1 to week 6 and the total chlorophyll ( $\mathrm{a}$ and $\mathrm{b}$ ) and total carotenoid contents were measured with the spectrophotometer methods from the above method.

Table 1. The summaries of liquid culture factors using in the experiment

\begin{tabular}{c|c|c|c}
\hline $\mathbf{p H}$ & Medium strength & $\mathbf{N a N O}_{\mathbf{3}}$ or nitrogen source & Vitamin $\mathbf{B}_{\mathbf{1 2}}$ or thiamine HCl solution \\
\hline 3.0 & $25 \%$ & -0.50 times & -0.50 times \\
5.0 & $50 \%$ & -0.25 times & -0.25 times \\
7.0 & $75 \%$ & 0 times & 0 times \\
9.0 & $100 \%$ & 0.25 times & 0.25 times \\
11.0 & $200 \%$ & 0.50 times & 0.50 times \\
\hline
\end{tabular}




\section{Statistical analysis}

These measurements were carried out with three replicates, and the results presented were the means of the three replicated experiments. Duncan's new multiple range test (DMRT) (ANOVA, $\alpha=0.05$ ) was used to determine the significant differences. The Jamovi statistic programming version 21.0 (The jamovi project, Sydney, Australia) was performed.

\section{Results}

\section{Morphologic characteristics of the algae}

The colonies of T. monilia that were sampled were crustose algae in thallus form found on a steel barrier along a trail in a dry evergreen forest at 700 metres above sea level. They had dark-green to yellow-greenish filaments. The thallus consisted of a dense mat with marked separations between the dense prostrate parts and slightly erect parts. The prostrate parts had a spreading form and produced a pseudoparenchymatous layer, which consisted of several layers of globular cells. The erect part had short filaments arising from the upper prostrate parts; they were 37.47 to $58.68 \mu \mathrm{m}$ tall, with a thin cell wall. The cells of the erect filaments had a globular, swollen or inflated shape and were 2.67 to $3.59 \mu \mathrm{m}$ wide and 4.21 to $3.60 \mu \mathrm{m}$ long. The lateral filaments branching in the central region and the apical cells were often slightly pointed, usually with a small pectic cap at the tip. Neither zoosporangia nor gametangia were observed in this habitat (Fig. 1).
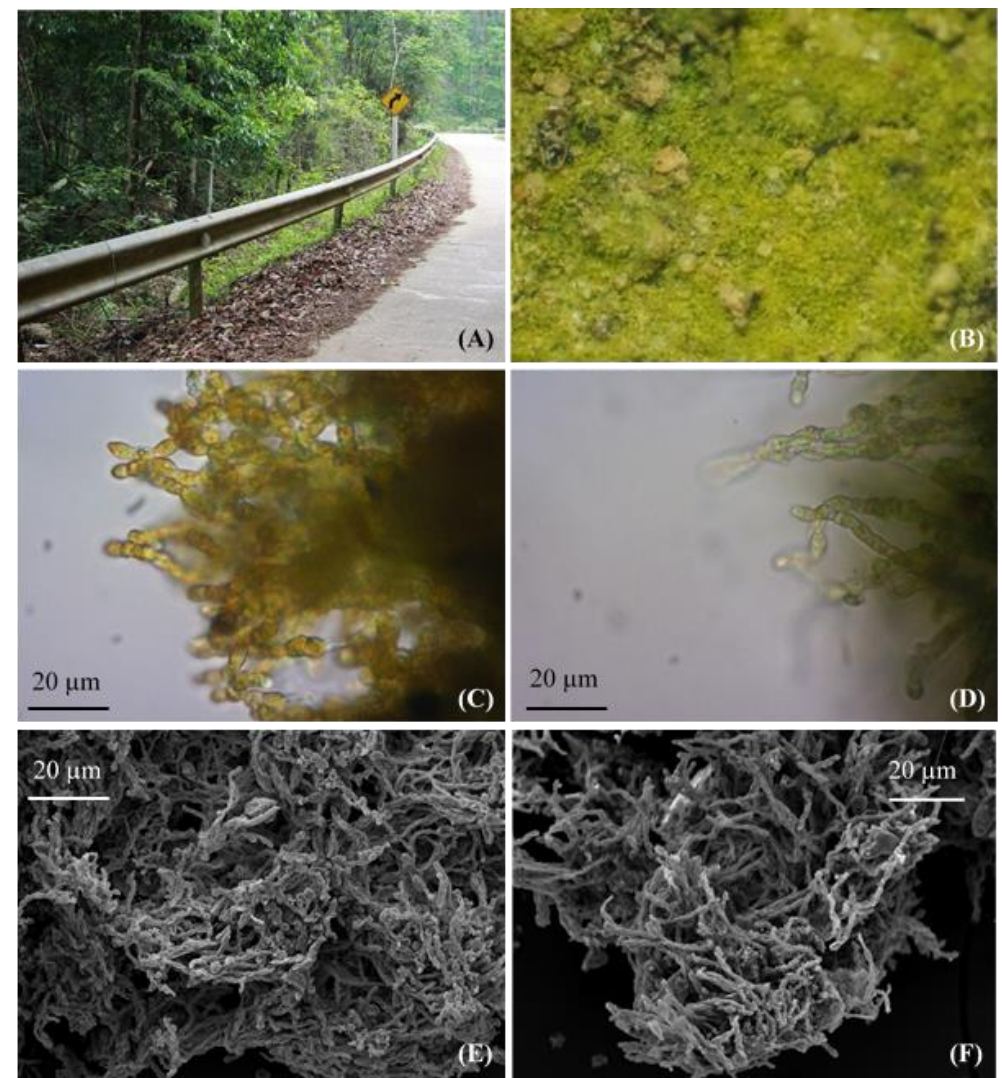

Figure 1. Characteristics of T. monilia. (A) Habitat from which algae were taken. (B) Cell morphologic characteristics as seen by the naked eye, $(C$ to $D)$ under the light compound microscope and $(E$ to $F$ ) by scanning electron microscopy 


\section{Growth of algae}

T. monilia samples from the Chiang Dao Wildlife Sanctuary were successfully grown and isolated only in ESM for 3 months (90 days) (Fig. 2). The ESM was used in culture for the analysis of the growth. After the cells had been placed in a fresh ESM culture for 3 months, the growth of T. monilia was measured by photosynthetic pigment methods to confirm the growth curves.

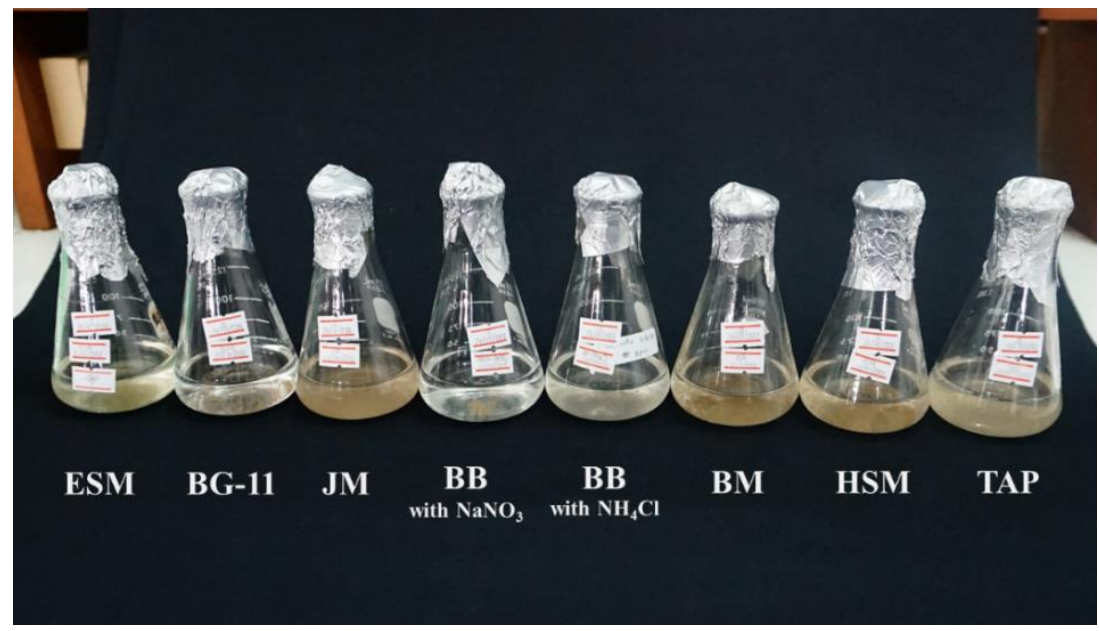

Figure 2. T. monilia cells culture at week 6 in 7 liquid media (liquid enrich seawater medium (ESM), liquid BG-11 medium, liquid Jawoski's medium (JM), liquid Bold's basal (BB) medium with $\mathrm{NaNO}_{3}$ or $\mathrm{NH}_{4} \mathrm{Cl}$ source, liquid Bristol medium (BM), liquid high salt medium (HSM) and liquid Tris acetate-phosphate (TAP) medium, respectively)

The growth of the T. monilia cells was measured by the photosynthetic pigments of the total chlorophyll ( $\mathrm{a}$ and $\mathrm{b}$ ) and total carotenoid content. In the media, the growth curve was the same growth pattern from week 1 to week 11, but we found that in the ESM, the growth was the highest in week 9 (p-value $\leq 0.05$ ) (Table A1). We found that the amounts of total chlorophyll were highest in week 9 , at $0.1793 \pm 0.0852 \mathrm{~g} / 1$, but the total carotenoid content was highest in week 11 , at $0.0530 \pm 0.0005 \mathrm{~g} / \mathrm{l}$. The ratio of total carotenoids to total chlorophyll did not vary much over the time of the study; it was $0.1800 \pm 0.0088$ to $0.4660 \pm 0.0852$ (see Fig. 3 and Fig. 4).

\section{Total carotenoid content of algae in various culture conditions}

The influence of different features of the cultures on the total carotenoid content accumulation of T. monilia varied. The effect of the $\mathrm{pH}$ on $T$. monilia growth, as shown in Fig. $5(A)$, and on the total carotenoid content was similar and changed quite a lot from week 1 to week 6 . The total carotenoid content at a pH of 5.0, 7.0, 9.0 or 11.0 were unpattern changed in all of the weeks, except in the final week, when it was very high (Table A2). It was highest at a $\mathrm{pH}$ of 7.0 , at $0.0273 \pm 0.0140 \mathrm{~g} / \mathrm{l}$ in week 6 . The effect of peptone on the T. monilia growth is shown in Fig. $5(\mathrm{C})$. The total carotenoid content with various amounts of peptone was similar in pattern and was also quite high from week 1 to week 6 (Table A3). The total carotenoid content with peptone of $0.5 \%$ and $1.0 \%$ changed the most from week 5 to week 6 , and peptone of $1.0 \%$ caused the most accumulation of total carotenoids $(0.0301 \pm 0.0000 \mathrm{~g} / \mathrm{l})$. The effect of the culture strength 
on T. monilia growth was shown in Table A4 and Fig. 6 (A). The total carotenoid content with various culture strengths had a similar pattern and changed quite a bit from week 1 to week 6 , similar to the peptone growth curve. At a culture strength of $50 \%$, the total carotenoid content had a positive pattern of accumulation from week 1 to week 6 . It was highest in week 6 , at $0.0256 \pm 0.0000 \mathrm{~g} / 1$. The effect of the nitrogen source on T. monilia growth was statistically significant (Table A5) and shown in Fig. $6(C)$. The total carotenoid content with various nitrogen sources had quite a similar pattern and was quite changed from week 1 to week 6 , just like the peptone growth and culture strength curves. The total carotenoid content had a positive pattern of accumulation from week 1 to week 6 when only $\mathrm{NaNO}_{3}$ was used at -0.50 and 0.50 times. $\mathrm{NaNO}_{3}$ of -0.50 times led to the highest accumulation of total carotenoids in the final week, at $0.0484 \pm 0.0004 \mathrm{~g} / \mathrm{l}$. Finally, the effect of vitamin $\mathrm{B}_{12}$ on the T. monilia growth was statistically significant (Table AO) and shown in Fig. 7 (A). The total carotenoid content with various vitamin $\mathrm{B}_{12}$ sources was quite similar and quite changed from week 1 to week 6 , like the peptone growth, culture strength and nitrogen source curves. With vitamin $B_{12}$ of -0.50 times, the total carotenoid content was found to be high from week 1 and highest in week 6 , at $0.0423 \pm 0.0000 \mathrm{~g} / 1$.
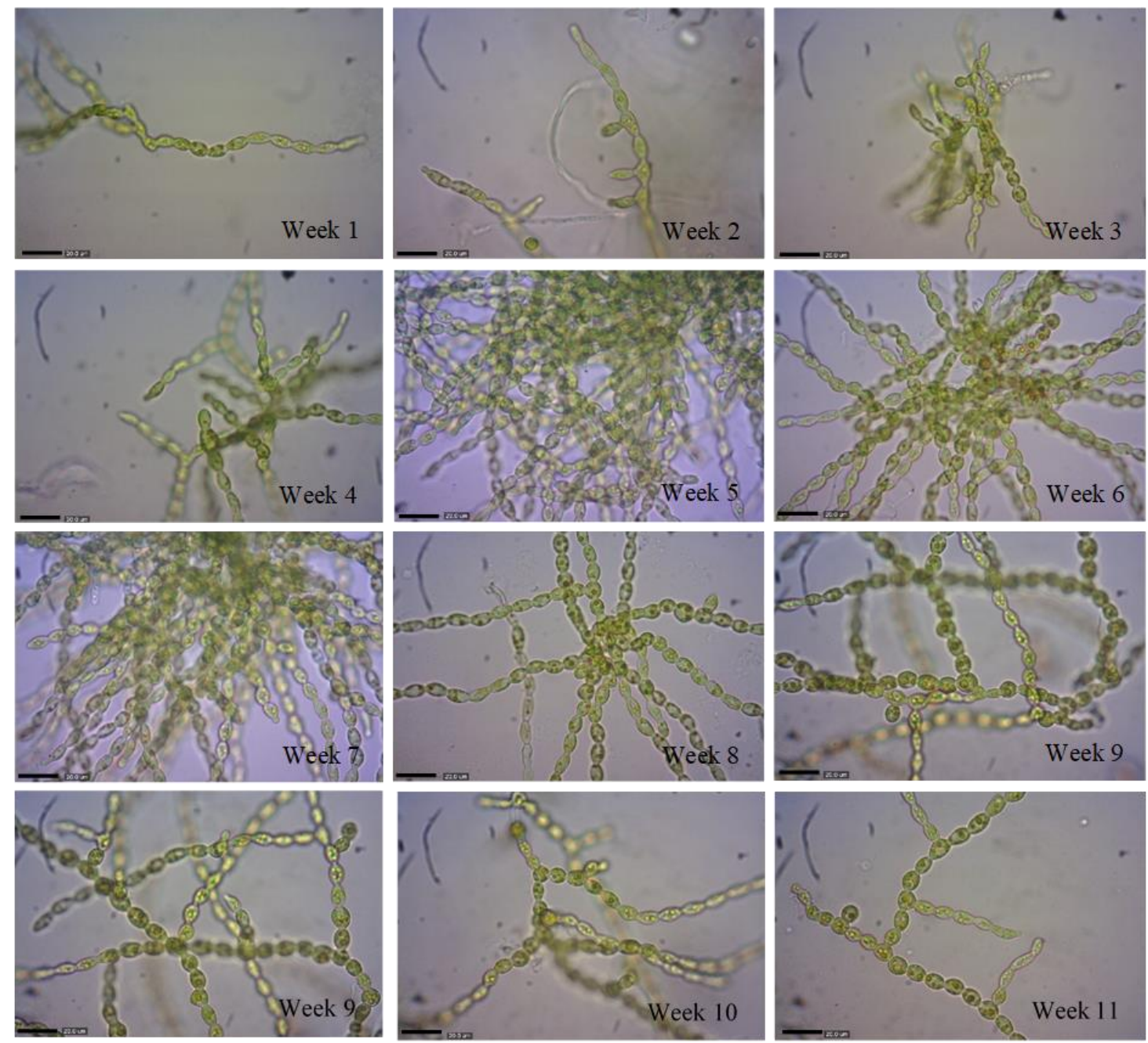

Figure 3. Characteristic cells of T. monilia in liquid ESM from week 1 to week 11 ( scale bars $=20 \mu \mathrm{m}$ ) 

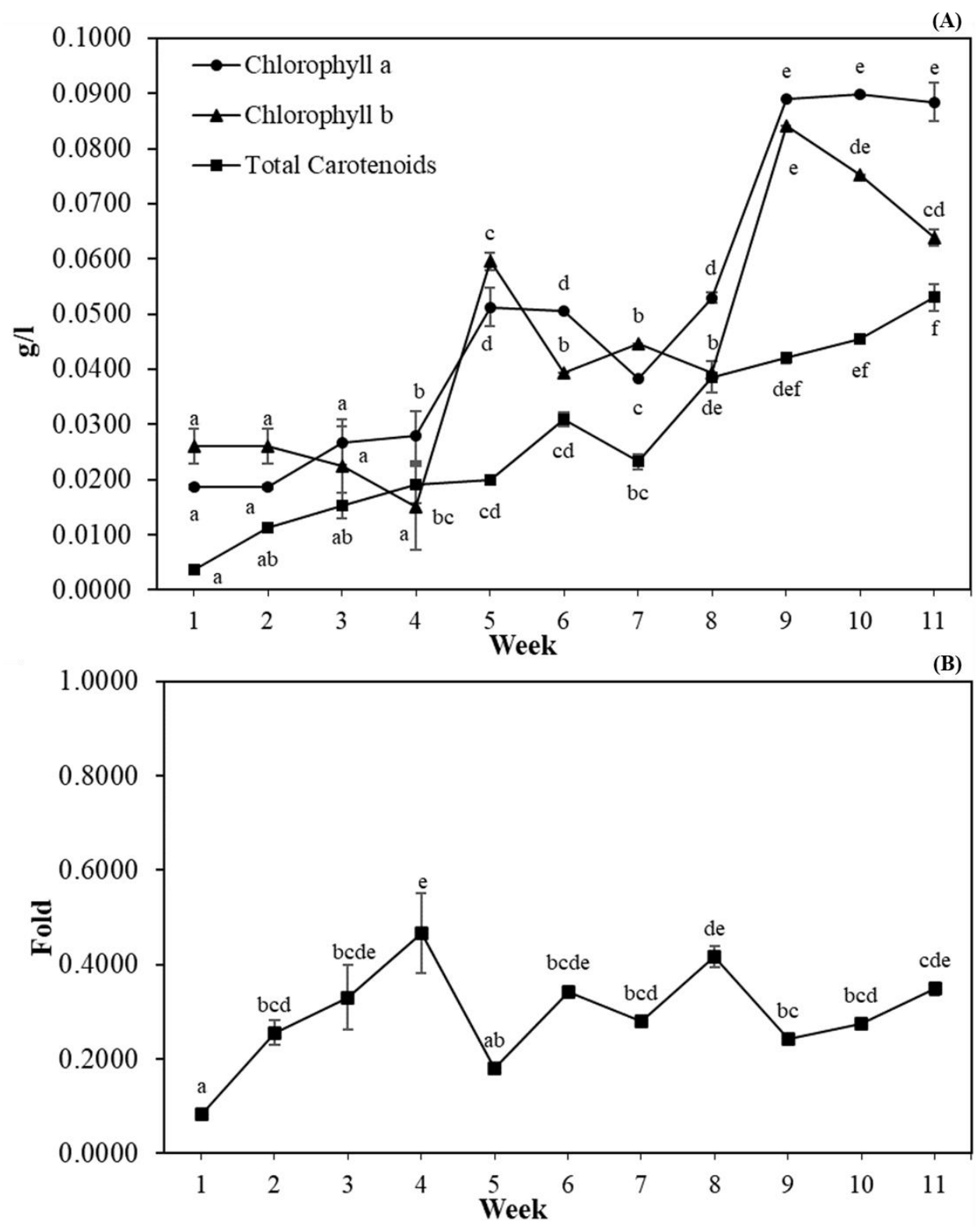

Figure 4. The growth of T. monilia in liquid ESM as measured by photosynthetic pigment methods. (A) Pigment accumulation and (B) total carotenoids/chlorophyll content ratios. Data are mean values of three replications and SE are indicated by the bar. The different letters indicate significant differences $(p \leq 0.05)$ at each time by DMRT

All of the measurements of the total carotenoids/total chlorophyll ratios for all of the culture factors are shown in Fig. $5(B, D)$, Fig. $6(B, D)$ and Fig. $7(B)$. The results were clear because the ratios changed in all of the weeks from week 1 to week 6 .

In the condition of $\mathrm{pH} 7$, added peptone $1 \%$, culture strength $50 \%$, nitrogen source -0.50 times and vitamin $\mathrm{B}_{12}$ source -0.50 times which nitrogen source -0.50 times from general concentration in enriched seawater medium (ESM) were the optimum of T. monilia growth to produce the increased of total carotenoids content more than total chlorophyll content accumulation in algae. 

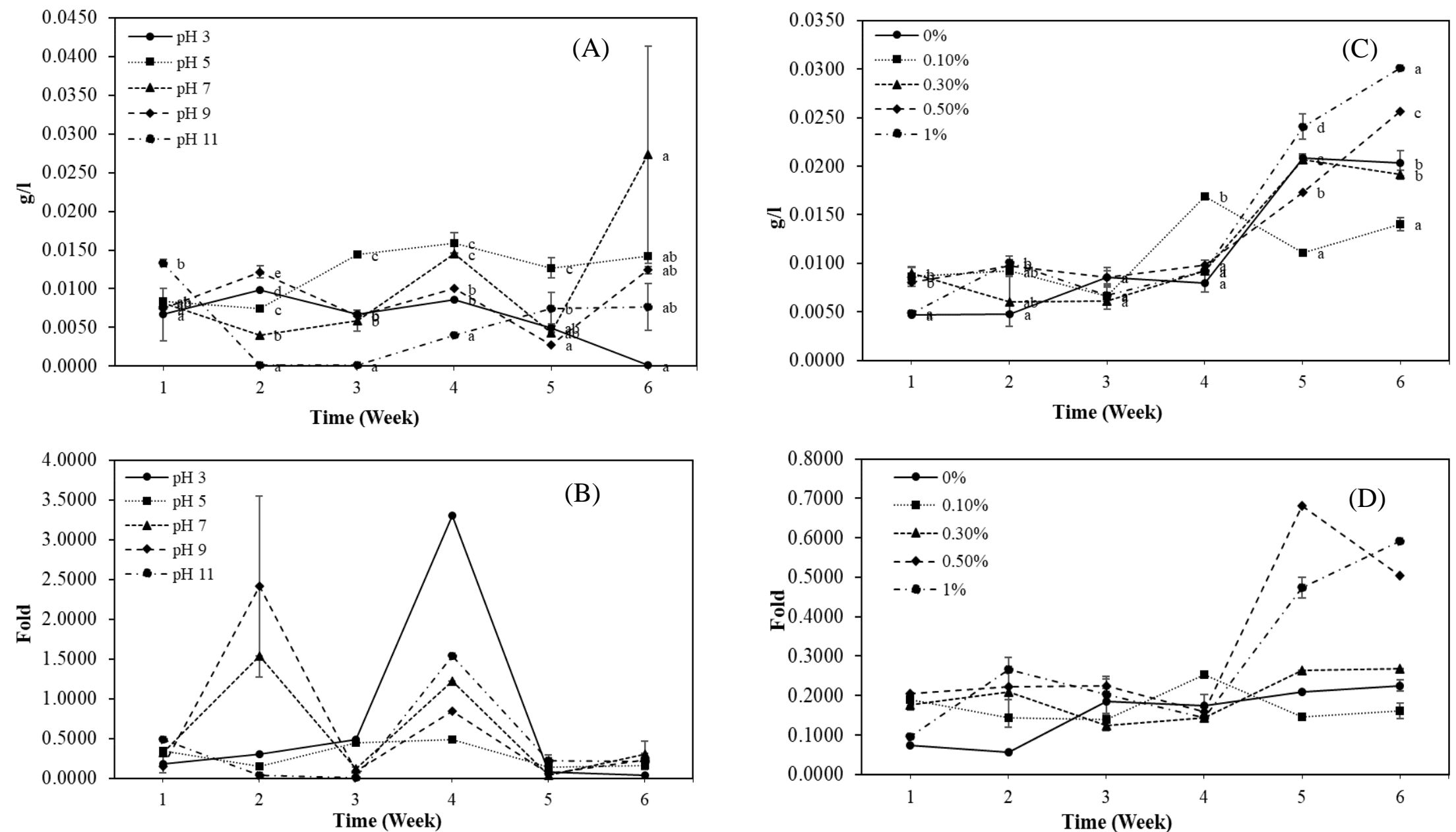

Figure 5. Evolution over time of the total carotenoid content and total carotenoid/total chlorophyll content of T. monilia in liquid ESM with various culture factors: $(A$ and $B) p H$, and $(C$ and $D)$ peptone. Data are mean values of three replications and SE are indicated by the bar. The different letters indicate significant differences $(p \leq 0.05)$ at each time by DMRT

APPLIED ECOLOGY AND ENVIRONMENTAL RESEARCH 19(3):2443-2458.

http://www.aloki.hu • ISSN 15891623 (Print) • ISSN 17850037 (Online)

DOI: http://dx.doi.org/10.15666/aeer/1903 24432458

(c) 2021, ALÖKI Kft., Budapest, Hungary 

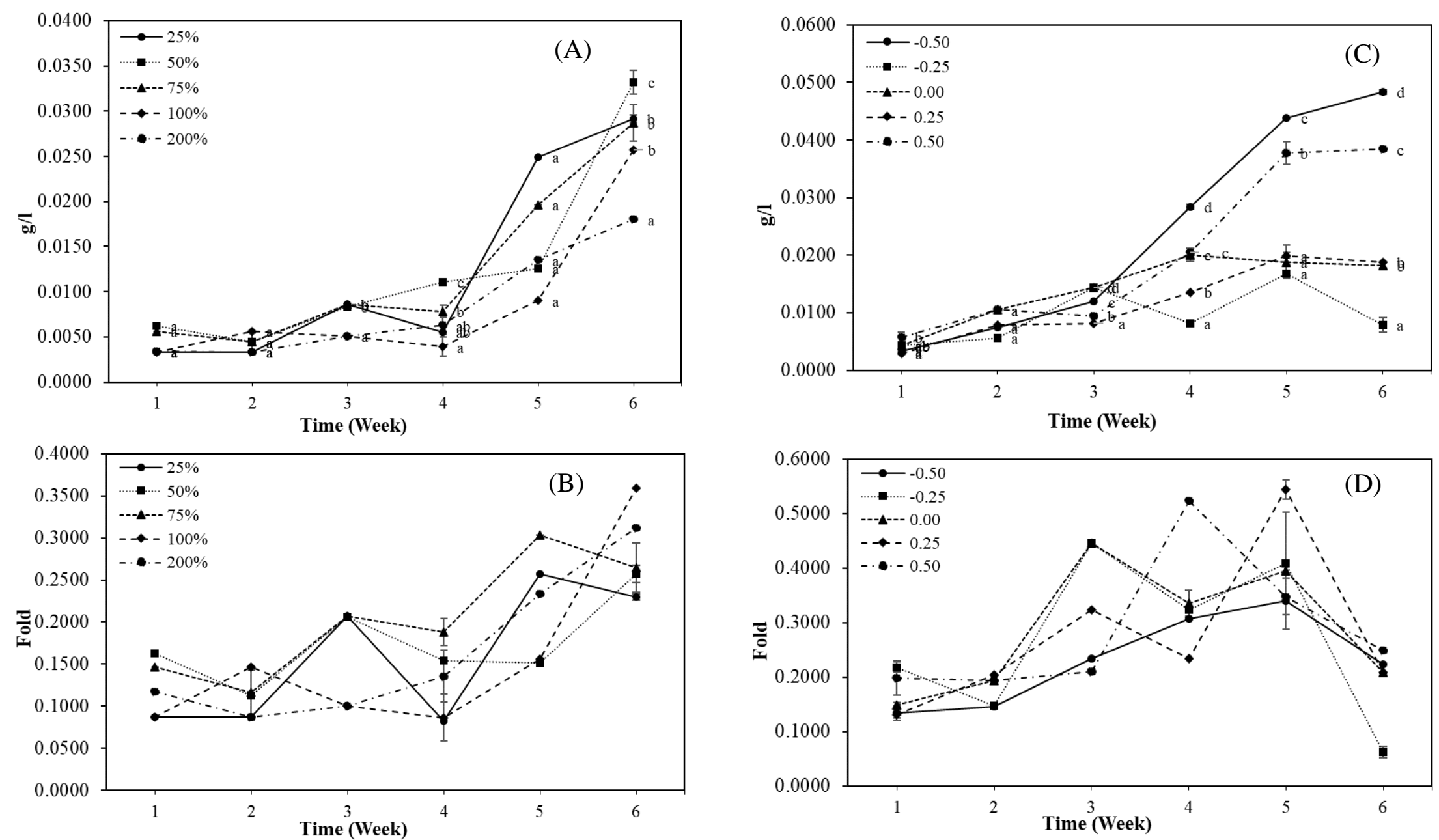

Figure 6. Evolution over time of the total carotenoid content and total carotenoid/total chlorophyll content of T. monilia in liquid ESM with various culture factors: $(A$ and $B)$ culture strength, and $(C$ and $D)$ nitrogen source. Data are mean values of three replications and $S E$ are indicated by the bar. The different letters indicate significant differences $(p \leq 0.05)$ at each time by DMRT 

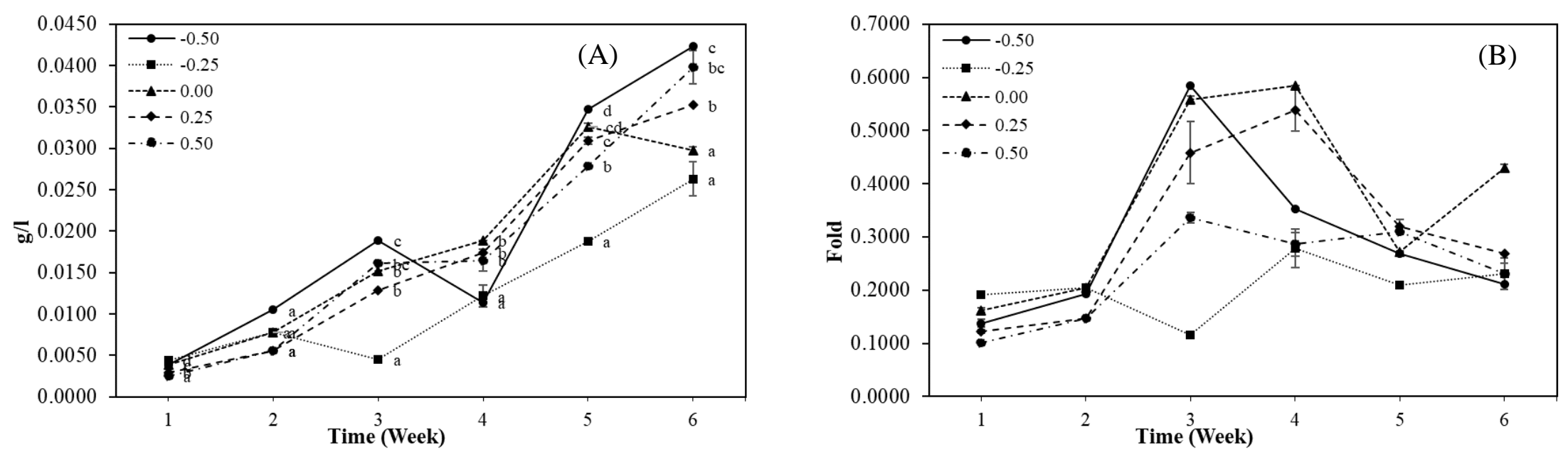

Figure 7. Evolution over time of the total carotenoid content and total carotenoid/total chlorophyll content of T. monilia in liquid ESM with various culture factors: $(A$ and $B)$ vitamin $B_{12}$ source. Data are mean values of three replications and SE are indicated by the bar. The different letters indicate significant differences $(p \leq 0.05)$ at each time by DMRT 


\section{Discussion}

Trentepohlia spp. grow mainly in tropical and subtropical zones of the world. They grow on tree barks, soils and rocks and also on manmade structures exposed to full sunlight (John, 2002; López-Bautista et al., 2002; Kharkongor and Ramanujam, 2017; Rindi et al., 2018). These algae are thought to have a high tolerance for and adaptability to extreme conditions such as desiccation and high temperatures (Rindi, 2007; Rindi et al., 2009; Bartoli et al., 2019; Binoy et al., 2019). As a source of useful substances, T. monilia has the negative characteristics of a longer lag phase and a lower growth rate than other microalgae grown in liquid cultures. This study showed that $T$. monilia grew the most and produced the most total carotenoid content only in ESM. According to Abe et al. (1998), who studied Trentepohlia aurea, the best growth also occurred in liquid ESM with 3,000 lux. The ESM has nutrients and properties of soil extraction similar to those of the natural habitats of Trentepohlia spp.

In terms of various growth factors, a $\mathrm{pH}$ of 6.0 to 8.0 is optimal for the growth of Trentepohlia spp. (Abe et al., 1999; Lemes-da-Silva et al., 2017). The optimum pH was 7.0 in a liquid culture, based on colony size, the relative abundance of new colonies formed and the dimensions of apical cells. The algae preferred a slightly alkaline ( $\mathrm{pH} 7.5)$ environment, although they could be grown in a wide range of $\mathrm{pH}$ conditions. The preference for an alkaline environment is not surprising. In nature, the species colonizes whitewashed building walls, as well as painted surfaces or manmade constructions, where the $\mathrm{pH}$ is distinctly alkaline (Lee et al., 1990; Lemes-da-Silva et al., 2017; Bartoli et al., 2019; Binoy et al., 2019). In the presence of peptone, the growth rate was even greater. Peptone supplementation activated nitrogen metabolism in the cells of T. monilia, resulting in an acceleration of the algal growth rate (Abe et al., 1998). An earlier study had shown that the growth rate and total chlorophyll content increased markedly with the addition of peptone as a nitrogen source. The culture strength, at nutrient strengths of $75 \%, 100 \%$ and $200 \%$, resulted in a normal-appearing growth rate and the cells remained green. Transferring the algae from a diluted $25 \%$ or $50 \%$ culture medium changed the color to yellow or orange (Lee et al., 1990), which was optimal for producing total carotenoids. With a nitrogen source of -0.50 times, the chlorophyll a content was the lowest. The carotenoid content was higher than the chlorophyll a content with the lowest nitrogen source (Chen et al., 2016). Nitrogen deficiency had a significantly positive effect on carotenoid accumulation in Trentepohlia arborum and other species in the same genus (Tan et al., 1993; Abe et al., 1998); this might have depended on high expression levels of enzymes involved in $\beta$-carotene synthesis, resembling that for Haematococcus pluvialis, when grown under nitrogen deficiency (Recht et al., 2014). The effect of a vitamin $B_{12}$ source or thiamine was negligible. It has been reported that vitamins are necessary for the growth of various groups of algae, but the growth of T. monilia in their presence was slow and have high total carotenoid content accumulation (Lee et al., 1990).

In the present study, the growth and accumulation of total carotenoids in the subaerial green alga T. monilia in liquid ESM were shown. It was thus possible to demonstrate the simultaneous production of useful materials such as $\beta$-carotene by $T$. monilia. The algae could be used to provide a rich source of foods or supplementary foods, natural food colourants, animal feeds, cosmetics and medicines. T. monilia could also be utilized as a biofunctional material in the future. This report provides new information on the nature of different carotenoids biosynthesized by $T$. monilia collected from natural sources without culturing the alga in an artificial medium. 


\section{Conclusion}

T. monilia grows the best in liquid ESM culture. The maximum growth occurred in week 9 of the study. The total carotenoids accumulated at the highest rate when the species was being grown in this culture. In ESM, the best liquid culture, the optimal conditions were a $\mathrm{pH}$ of 7.0 , peptone of $1 \%$, culture strength of $50 \%$, nitrogen source -0.50 times and vitamin $\mathrm{B}_{12}$ source -0.50 times the normal concentration. This culture produced the optimum growth of $T$. monilia, the highest amount of total carotenoids and situations in which the total carotenoids were higher than the total chlorophyll in a liquid culture. In further studies, we will focus on modifying more specialized ESM mediums to optimize for a short period to cultivate $T$. monilia less than three weeks, which should be promising for future carotenoid-producing industries.

Acknowledgements. This research was supported by the Kasetsart University Research and Development Institute (KURDI), the Science Achievement Scholarship of Thailand, and the Faculty of Science, Kasetsart University. We thank our colleagues from the Chiang Dao Wildlife Sanctuary for facilitating.

\section{REFERENCES}

[1] Abe, K., Mihara, H., Hirano, M. (1998): Characteristics of growth and carotenoid accumulation of the aerial microalga Trentepohlia aurea in liquid culture. - Journal of Marine Biotechnology 6(1): 53-58.

[2] Abe, K., Nishimura, N., Hirano, M. (1999): Simultaneous production of $\beta$-carotene, vitamin e and vitamin c by the aerial microalga Trentepohlia aurea. - Journal of Applied Phycology 11(4): 331-336.

[3] Aburai, N., Ohkubo, S., Miyashita, H., Abe, K. (2013): Composition of carotenoids and identification of aerial microalgae isolated from the surface of rocks in mountainous districts of Japan. - Algal Research 2(3): 237-243.

[4] Allali, H. A. (2011): Biodiversity and Molecular Systematics of Subaerial Algae frometersfrica and the Neotropics. - Ph.D. dissertation, University of Alabama, Alabama.

[5] Bartoli, F., Ellwood, N. T. W., Bruno, L., Ceschin, S., Rugnini, L., Caneva, G. (2019): Ecological and taxonomic characterisation of Trentepohlia umbrina (Kützing) Bornet growing on stone surfaces in Lazio (Italy). - Annals of Microbiology 69: 1059-1070.

[6] Binoy, T. T., Bhagya, M. V., Thomas, V. P. (2019): Epiphyllous algae of Trentepohlia Martius in Southwestern Ghats, India, including one new species and three new records. Taiwania 64(2): 103-110.

[7] Cazzonelli, C. I. (2011): Carotenoids in nature: insights from plants and beyond. Functional Plant Biology 38(11): 833-847.

[8] Chen, L., Zhang, L., Zhang, W., Liu, T. (2015): Comparative analysis of growth and carotenoid accumulation of Trentepohlia arborum in aerial, subaerial, and aquatic cultivation. - Journal of Applied Phycology 27(3): 1079-1087.

[9] Chen, L., Zhang, L., Liu, T. (2016): Concurrent production of carotenoids and lipid by a filamentous microalga Trentepohlia arborum. - Bioresource Technology 214: 567-573.

[10] Czeczuga, B., Maximov, O. M. (1996): Carotenoids in the cells of the alga Trentepohlia gobii Meyer. - Acta Societatis Botanicorum Poloniae 65(3-4): 273-276.

[11] Eldahshan, O. A., Singab, A. N. B. (2013): Carotenoids. - Journal of Pharmacognosy and Phytochemistry 2(1): 225-234.

[12] Guedes, A. C., Amaro, H. M., Malcata, F. X. (2011): Microalgae as sources of carotenoids. - Marine Drug 9(4): 625-644. 
[13] Guiry, M. D., Guiry, G. M. (2015): Algae Base. - http://www.algaebase.org/search/ genus/detail/?genus_id=P34e5de6b47fb6fc9\&-session=abv4:AC1F1A8E13da614322Yrr 5EF57B0.

[14] John, D. M. (2002): Phylum Chlorophyta (Green Algae). - In: John, D. M., Whitton, B. A., Brook, A. J. (eds.) The Freshwater Algal Flora of the British Isles. Cambridge University Press, Cambridge.

[15] John, D. M. (2003): Filamentous and Plantlike Green Algae. - In: Wehr, J. D., Sheath, R. G. (eds.) Freshwater Algae of North America: Ecology and Classification. Academic Press, Amsterdam.

[16] Kharkongor, D., Ramanujam, P. (2017): Antioxidant activities of four dominant species of Trentepohlia (Trentepohliales, Chlorophyta). - Internationa Journal of Complementary \& Alternative Medicine 8(5): 1-7.

[17] Lee, C. T., Wee, Y. C., Ho, K. K. (1990): Growth and Development of Trentepohlia Odorata in Culture, Culture and Use of Algae in Southeast Asia. - In: Proceedings the Symposium on Culture and Utilization of Algae in Southeast Asia. 8-11 December 1981, Tigbauan, Iloilo, Philippines.

[18] Lemes-da-Silva, N. M., Garey, M. V., Branco, L. H. Z. (2017): Floristic diversity, richness and distribution of Trentepohliales (Chlorophyta) in Neotropical ecosystems. - Brazilian Journal of Botany 40: 883-896.

[19] López-Bautista, J. M., Waters, D. A., Chapman, R. L. (2002): The Trentepohliales: revisited. - Constancea 83, http://ucjeps.berkeley.edu/constancea/83/lopez_etal/trentepohliales.html.

[20] López-Bautista, J. M. (2008): Subaerial Algae in Tropical Rainforests. - Subaerial Algae, https://stri-sites.si.edu/sites/taxonomy_training/Docs/phycology_docs/LopezPart1.pdf.

[21] Mortensen, A. (2006): Carotenoids and other pigments as natural colorants. - Pure and Applied Chemistry 78(8): 1477-1491.

[22] Mukherjee, R., Borah, S. P., Goswami, B. C. (2010): Biochemical characterization of carotenoids in two species of Trentepohlia (Trentepohliales, Chlorophyta). - Journal of Applied Phycology 22(5): 569-571.

[23] Pompelli, M. F., França, S. C., Tigre, R. C., de Oliveira, M. T., Sacilot, M., Pereira, E. C. (2013): Spectrophotometric determinations of chloroplastidic pigments in acetone, ethanol and dimethylsulphoxide. - Brazilian Journal of Biological Sciences 11(1): 52-58.

[24] Priyadarshani, I., Rath, B. (2012): Commercial and industrial applications of microalgae: a review. - Journal of Algal Biomass Utilization 3(4): 89-100.

[25] Rao, A. V., Rao, L. G. (2007): Carotenoids and human health. - Pharmacological Research 55: 207-216.

[26] Recht, L., Topfer, N., Batushansky, A., Sikron, N., Gibon, Y., Fait, A., Nikoloski, Z., Boussiba, S., Zarka, A. (2014): Metabolite profiling and integrative modeling reveal metabolic constraints for carbon partitioning under nitrogen starvation in the green algae Haematococcus pluvialis. - Journal of Biological Chemistry 289(44): 30387-30403.

[27] Rindi, F. (2007): Diversity, Distribution and Ecology of Green Algae and Cyanobacteria in Urban Habitats. - In: Seckbach, J. (ed.) Algae and Cyanobacteria in Extreme Environments. Springer, Dordrecht, The Netherlands.

[28] Rindi, F., Allali, H. A., Lam, D. W., López-Bautista, J. M. (2009): An Overview of The Biodiversity and Biogeography of Terrestrial Green Algae. - In: Rescigno, V., Maletta, S. (eds.) Biodiversity Hotspots. Nova Science Publishers, New York.

[29] Rindi, F., Sikes, J., Shapiro, L. (2018): The identity of Trentepohlia algae (Chlorophyta: Trentepohliales) from Point Lobos State Reserve and The San Francisco Region, California. - Madroño 65(2): 89-95.

[30] Saraphol, S., Vajrodaya, S., Kraichak, E., Sirikhachornkit, A., Sanevas, N. (2020): Environmental factors affecting the diversity and photosynthetic pigments of Trentepohlia species in northern Thailand's Chiang Dao Wildlife Sanctuary. - Acta Societatis Botanicorum Poloniae 89(1): 1-24. 
[31] Takaichi, S. (2011): Carotenoids in algae: distributions, biosyntheses and functions. Marine Drugs 9(6): 1101-1118.

[32] Tan, C. K., Lee, Y. K., Ho, K. K. (1993): Effect of light intensity and ammonium-N on carotenogenesis of Trentepohlia odorata and Dunaliella bardawil. - Journal of Applied Phycology 5(5): 547-549.

\section{APPENDIX}

Table A1. ANOVA analysis results of growth of T. monilia in liquid ESM medium which measured by chlorophyll-a, chlorophyll-b and total carotenoids content from week 1 to week 11

\begin{tabular}{c|c|c|c|c}
\hline Source & df & Mean square & F & Sig. \\
\hline Intercept & 1 & 0.083 & 3612.965 & .000 \\
Chlorophyll a & 10 & 0.002 & 100.561 & .000 \\
Error & 22 & 0.00002302 & & \\
Total & 33 & 0.067 & 1322.438 & .000 \\
\hline Intercept & 1 & 0.002 & 30.756 & .000 \\
Chlorophyll b & 10 & 0.00005071 & & \\
Error & 22 & & & .000 \\
Total & 33 & 0.027 & 499.133 & .000 \\
\hline Intercept & 1 & 0.001 & 13.330 & \\
Total Carotenoids & 10 & 0.00005392 & & \\
Error & 22 & & & \\
Total & 33 & &
\end{tabular}

Table A2. ANOVA analysis results of total carotenoids content in T. monilia on ESM medium with a different $\mathrm{pH}$ on week 1 to week 6

\begin{tabular}{|c|c|c|c|c|}
\hline Source & df & Mean square & $\mathbf{F}$ & Sig. \\
\hline $\begin{array}{c}\text { Intercept } \\
\mathrm{pH}(\text { Week 1) } \\
\text { Error } \\
\text { Total }\end{array}$ & $\begin{array}{c}1 \\
4 \\
10 \\
15\end{array}$ & $\begin{array}{c}0.001 \\
0.00002067 \\
0.000009174\end{array}$ & $\begin{array}{c}126.811 \\
2.253\end{array}$ & $\begin{array}{l}.000 \\
.136\end{array}$ \\
\hline $\begin{array}{c}\text { Intercept } \\
\mathrm{pH}(\text { Week 2) } \\
\text { Error } \\
\text { Total }\end{array}$ & $\begin{array}{c}1 \\
4 \\
10 \\
15\end{array}$ & $\begin{array}{c}0.001 \\
0.00006813 \\
0.0000005227\end{array}$ & $\begin{array}{c}1285.735 \\
130.342\end{array}$ & $\begin{array}{l}.000 \\
.000\end{array}$ \\
\hline $\begin{array}{c}\text { Intercept } \\
\mathrm{pH}(\text { Week 3) } \\
\text { Error } \\
\text { Total }\end{array}$ & $\begin{array}{c}1 \\
4 \\
10 \\
15\end{array}$ & $\begin{array}{c}0.001 \\
0.00007769 \\
0.000001453\end{array}$ & $\begin{array}{c}464.237 \\
53.456\end{array}$ & $\begin{array}{l}.000 \\
.000\end{array}$ \\
\hline $\begin{array}{c}\text { Intercept } \\
\mathrm{pH}(\text { Week 4) } \\
\text { Error } \\
\text { Total }\end{array}$ & $\begin{array}{c}1 \\
4 \\
10 \\
15\end{array}$ & $\begin{array}{c}0.002 \\
0.00006841 \\
0.000001350\end{array}$ & $\begin{array}{c}1248.444 \\
50.678\end{array}$ & $\begin{array}{l}.000 \\
.000\end{array}$ \\
\hline $\begin{array}{c}\text { Intercept } \\
\mathrm{pH}(\text { Week 5) } \\
\text { Error } \\
\text { Total } \\
\end{array}$ & $\begin{array}{c}1 \\
4 \\
10 \\
15 \\
\end{array}$ & $\begin{array}{c}0.001 \\
0.00004526 \\
0.000004787\end{array}$ & $\begin{array}{c}129.948 \\
9.453\end{array}$ & $\begin{array}{l}.000 \\
.002\end{array}$ \\
\hline $\begin{array}{c}\text { Intercept } \\
\mathrm{pH}(\text { Week 6) } \\
\text { Error } \\
\text { Total } \\
\end{array}$ & $\begin{array}{c}1 \\
4 \\
10 \\
15\end{array}$ & $\begin{array}{l}0.002 \\
0.000 \\
0.000\end{array}$ & $\begin{array}{c}13.860 \\
1.818\end{array}$ & $\begin{array}{l}.004 \\
.202\end{array}$ \\
\hline
\end{tabular}


Table A3. ANOVA analysis results of total carotenoids content in T. monilia on ESM medium with a different peptone (\%) on week 1 to week 6

\begin{tabular}{|c|c|c|c|c|}
\hline Source & dff & Mean square & $\mathbf{F}$ & Sig. \\
\hline $\begin{array}{c}\text { Intercept } \\
\text { peptone (Week 1) } \\
\text { Error } \\
\text { Total }\end{array}$ & $\begin{array}{c}1 \\
4 \\
10 \\
15\end{array}$ & $\begin{array}{c}0.001 \\
0.00001314 \\
0.000001287\end{array}$ & $\begin{array}{c}576.697 \\
10.214\end{array}$ & $\begin{array}{l}.000 \\
.001\end{array}$ \\
\hline $\begin{array}{c}\text { Intercept } \\
\text { peptone (Week 2) } \\
\text { Error } \\
\text { Total } \\
\end{array}$ & $\begin{array}{c}1 \\
4 \\
10 \\
15\end{array}$ & $\begin{array}{c}0.001 \\
0.00001722 \\
0.000006103\end{array}$ & $\begin{array}{c}156.244 \\
2.821\end{array}$ & $\begin{array}{l}.000 \\
.084\end{array}$ \\
\hline $\begin{array}{c}\text { Intercept } \\
\text { peptone (Week 3) } \\
\text { Error } \\
\text { Total }\end{array}$ & $\begin{array}{c}1 \\
4 \\
10 \\
15\end{array}$ & $\begin{array}{c}0.001 \\
0.000004094 \\
0.0000024658\end{array}$ & $\begin{array}{c}326.392 \\
1.666\end{array}$ & $\begin{array}{l}.000 \\
.233\end{array}$ \\
\hline $\begin{array}{c}\text { Intercept } \\
\text { peptone (Week 4) } \\
\text { Error } \\
\text { Total } \\
\end{array}$ & $\begin{array}{c}1 \\
4 \\
10 \\
15\end{array}$ & $\begin{array}{c}0.002 \\
0.00003839 \\
0.0000008887\end{array}$ & $\begin{array}{c}1901.323 \\
43.197\end{array}$ & $\begin{array}{l}.000 \\
.000\end{array}$ \\
\hline $\begin{array}{c}\text { Intercept } \\
\text { peptone (Week 5) } \\
\text { Error } \\
\text { Total } \\
\end{array}$ & $\begin{array}{c}1 \\
4 \\
10 \\
15 \\
\end{array}$ & $\begin{array}{c}0.005 \\
0.00007277 \\
0.000001731\end{array}$ & $\begin{array}{c}3062.149 \\
42.029\end{array}$ & $\begin{array}{l}.000 \\
.000\end{array}$ \\
\hline $\begin{array}{c}\text { Intercept } \\
\text { peptone (Week 6) } \\
\text { Error } \\
\text { Total } \\
\end{array}$ & $\begin{array}{c}1 \\
4 \\
10 \\
15\end{array}$ & $\begin{array}{c}0.007 \\
0.000 \\
0.000001905\end{array}$ & $\begin{array}{c}3751.864 \\
60.454\end{array}$ & $\begin{array}{l}.000 \\
.000\end{array}$ \\
\hline
\end{tabular}

Table A4. ANOVA analysis results of total carotenoids content in T. monilia on ESM medium with a different culture strength (\%) on week 1 to week 6

\begin{tabular}{|c|c|c|c|c|}
\hline Source & df & Mean square & $\mathbf{F}$ & Sig. \\
\hline $\begin{array}{c}\text { Intercept } \\
\text { Culture strength (Week 1) } \\
\text { Error } \\
\text { Total }\end{array}$ & $\begin{array}{c}1 \\
4 \\
10 \\
15\end{array}$ & $\begin{array}{c}0.000 \\
0.000006069 \\
0.000\end{array}$ & . & . \\
\hline $\begin{array}{c}\text { Intercept } \\
\text { Culture strength (Week 2) } \\
\text { Error } \\
\text { Total }\end{array}$ & $\begin{array}{c}1 \\
4 \\
10 \\
15\end{array}$ & $\begin{array}{c}0.000 \\
0.000002766 \\
0.000001633\end{array}$ & $\begin{array}{c}163.030 \\
1.693\end{array}$ & $\begin{array}{l}.000 \\
.227\end{array}$ \\
\hline $\begin{array}{c}\text { Intercept } \\
\text { Culture strength (Week 3) } \\
\text { Error } \\
\text { Total }\end{array}$ & $\begin{array}{c}1 \\
4 \\
10 \\
15\end{array}$ & $\begin{array}{c}0.001 \\
0.00001051 \\
0.00000004267\end{array}$ & $\begin{array}{c}17956.000 \\
246.273\end{array}$ & $\begin{array}{l}.000 \\
.000\end{array}$ \\
\hline $\begin{array}{c}\text { Intercept } \\
\text { Culture strength (Week 4) } \\
\text { Error } \\
\text { Total }\end{array}$ & $\begin{array}{c}1 \\
4 \\
10 \\
15\end{array}$ & $\begin{array}{c}0.001 \\
0.00002219 \\
0.000002084\end{array}$ & $\begin{array}{c}344.008 \\
10.650\end{array}$ & $\begin{array}{l}.000 \\
.001\end{array}$ \\
\hline $\begin{array}{c}\text { Intercept } \\
\text { Culture strength (Week 5) } \\
\text { Error } \\
\text { Total }\end{array}$ & $\begin{array}{c}1 \\
4 \\
10 \\
15\end{array}$ & $\begin{array}{l}0.004 \\
0.000 \\
0.000\end{array}$ & . & . \\
\hline $\begin{array}{c}\text { Intercept } \\
\text { Culture strength (Week 6) } \\
\text { Error } \\
\text { Total }\end{array}$ & $\begin{array}{c}1 \\
4 \\
10 \\
15\end{array}$ & $\begin{array}{c}0.011 \\
0.00009633 \\
0.000004787\end{array}$ & $\begin{array}{c}2274.012 \\
20.122\end{array}$ & $\begin{array}{l}.000 \\
.000\end{array}$ \\
\hline
\end{tabular}


Table A5. ANOVA analysis results of total carotenoids content in T. monilia on ESM medium with a different nitrogen source (times) on week 1 to week 6

\begin{tabular}{|c|c|c|c|c|}
\hline Source & df & Mean square & $\mathbf{F}$ & Sig. \\
\hline $\begin{array}{c}\text { Intercept } \\
\text { Nitrogen source (Week 1) } \\
\text { Error } \\
\text { Total }\end{array}$ & $\begin{array}{c}1 \\
4 \\
10 \\
15\end{array}$ & $\begin{array}{c}0.000 \\
0.000003656 \\
0.0000007527\end{array}$ & $\begin{array}{c}339.381 \\
4.857\end{array}$ & $\begin{array}{l}0.000 \\
0.019\end{array}$ \\
\hline $\begin{array}{c}\text { Intercept } \\
\text { Nitrogen source (Week 2) } \\
\text { Error } \\
\text { Total } \\
\end{array}$ & $\begin{array}{c}1 \\
4 \\
10 \\
15\end{array}$ & $\begin{array}{c}0.001 \\
0.00001351 \\
0.000\end{array}$ & . & . \\
\hline $\begin{array}{c}\text { Intercept } \\
\text { Nitrogen source (Week 3) } \\
\text { Error } \\
\text { Total } \\
\end{array}$ & $\begin{array}{c}1 \\
4 \\
10 \\
15\end{array}$ & $\begin{array}{c}0.002 \\
0.00002411 \\
0.00000005400\end{array}$ & $\begin{array}{c}37765.444 \\
446.556\end{array}$ & $\begin{array}{l}.000 \\
.000\end{array}$ \\
\hline $\begin{array}{c}\text { Intercept } \\
\text { Nitrogen source (Week 4) } \\
\text { Error } \\
\text { Total } \\
\end{array}$ & $\begin{array}{c}1 \\
4 \\
10 \\
15 \\
\end{array}$ & $\begin{array}{c}0.005 \\
0.000 \\
0.000001241\end{array}$ & $\begin{array}{c}3975.497 \\
141.990\end{array}$ & $\begin{array}{l}.000 \\
.000\end{array}$ \\
\hline $\begin{array}{c}\text { Intercept } \\
\text { Nitrogen source (Week 5) } \\
\text { Error } \\
\text { Total } \\
\end{array}$ & $\begin{array}{c}1 \\
4 \\
10 \\
15\end{array}$ & $\begin{array}{c}0.011 \\
0.000 \\
0.00001015\end{array}$ & $\begin{array}{c}1111.761 \\
45.605\end{array}$ & $\begin{array}{l}0.000 \\
0.000\end{array}$ \\
\hline $\begin{array}{c}\text { Intercept } \\
\text { Nitrogen source (Week 6) } \\
\text { Error } \\
\text { Total }\end{array}$ & $\begin{array}{c}1 \\
4 \\
10 \\
15\end{array}$ & $\begin{array}{c}0.010 \\
0.001 \\
0.000001731\end{array}$ & $\begin{array}{c}6013.979 \\
474.511\end{array}$ & $\begin{array}{l}.000 \\
.000\end{array}$ \\
\hline
\end{tabular}

Table A6. ANOVA analysis results of total carotenoids content in T. monilia on ESM medium with a different vitamin $B_{12}$ source (times) on week 1 to week 6

\begin{tabular}{|c|c|c|c|c|}
\hline Source & df & Mean square & $\mathbf{F}$ & Sig. \\
\hline $\begin{array}{c}\text { Intercept } \\
\text { vitamin } \mathrm{B}_{12} \text { source (Week 1) } \\
\text { Error } \\
\text { Total }\end{array}$ & $\begin{array}{c}1 \\
4 \\
10 \\
15\end{array}$ & $\begin{array}{c}0.000 \\
0.000001882 \\
0.00000005267\end{array}$ & $\begin{array}{c}3555.696 \\
35.728\end{array}$ & $\begin{array}{l}0.000 \\
0.000\end{array}$ \\
\hline $\begin{array}{c}\text { Intercept } \\
\text { vitamin } \mathrm{B}_{12} \text { source (Week 2) } \\
\text { Error } \\
\text { Total }\end{array}$ & $\begin{array}{c}1 \\
4 \\
10 \\
15\end{array}$ & $\begin{array}{c}0.001 \\
0.00001229 \\
0.000\end{array}$ & . & . \\
\hline $\begin{array}{c}\text { Intercept } \\
\text { vitamin } \mathrm{B}_{12} \text { source (Week 3) } \\
\text { Error } \\
\text { Total } \\
\end{array}$ & $\begin{array}{c}1 \\
4 \\
10 \\
15 \\
\end{array}$ & $\begin{array}{c}0.003 \\
0.00009016 \\
0.000003267\end{array}$ & $\begin{array}{c}838.516 \\
27.599\end{array}$ & $\begin{array}{l}.000 \\
.000\end{array}$ \\
\hline $\begin{array}{c}\text { Intercept } \\
\text { vitamin } \mathrm{B}_{12} \text { source (Week 4) } \\
\text { Error } \\
\text { Total } \\
\end{array}$ & $\begin{array}{c}1 \\
4 \\
10 \\
15\end{array}$ & $\begin{array}{c}0.004 \\
0.00003272 \\
0.000004050\end{array}$ & $\begin{array}{c}864.735 \\
8.079\end{array}$ & $\begin{array}{l}.000 \\
.004\end{array}$ \\
\hline $\begin{array}{c}\text { Intercept } \\
\text { vitamin } \mathrm{B}_{12} \text { source (Week 5) } \\
\text { Error } \\
\text { Total } \\
\end{array}$ & $\begin{array}{c}1 \\
4 \\
10 \\
15 \\
\end{array}$ & $\begin{array}{c}0.013 \\
0.000 \\
0.000001561\end{array}$ & $\begin{array}{c}8075.653 \\
74.217\end{array}$ & $\begin{array}{l}0.000 \\
0.000\end{array}$ \\
\hline $\begin{array}{c}\text { Intercept } \\
\text { vitamin } \mathrm{B}_{12} \text { source (Week 6) } \\
\text { Error } \\
\text { Total }\end{array}$ & $\begin{array}{c}1 \\
4 \\
10 \\
15\end{array}$ & $\begin{array}{c}0.018 \\
0.000 \\
0.000006875\end{array}$ & $\begin{array}{c}2626.223 \\
19.499\end{array}$ & $\begin{array}{l}.000 \\
.000\end{array}$ \\
\hline
\end{tabular}

